\title{
Evaluation of Dermatology Consultations Requested From The Pediatric Clinic
}

\section{Pediatri Kliniğinden İstenen Dermatoloji Konsültasyonlarının Değerlendirilmesi}

\author{
'Cahit Yavuz (D) 2Cüneyt Uğur (D)
}

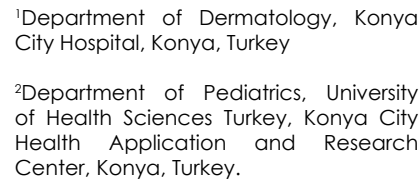

${ }^{2}$ Department of Pediatrics, University of Health Sciences Turkey, Konya City Health Application and Research Center, Konya, Turkey.

Correspondence

Cahit Yavuz, Akabe Mah. 42020 Karatay, KONYA.

E-Mail: yavuzcahit@yahoo.com

How to cite?

Yavuz C, Uğur C. Evaluation of Dermatology Consultations Requested From The Pediatric Clinic Genel Tip Derg. 2022;32(1):68-71.

\begin{abstract}
Objective: The aim of this study was to evaluate the clinical, demographic, and diagnostic characteristics of pediatric patients consulted to the dermatology department.

Methods: Patients who were consulted to the dermatology department from pediatric clinic of Konya City Hospital between January 2021 and August 2021 were scanned retrospectively. The demographic data of the patients, the pediatric department requesting consultation, their complaints at admission, the reasons for asking for consultation, and the diagnoses they received as a result of the consultation were recorded.

Results: A total of 296 patients, 150 (50.7\%) females and 146 (49.3\%) males were evaluated. Median age of patients was 5.5 (1.5-10.5) years. The outpatient clinic was seen to have made the most requests for consultation. The most frequent complaints on presentation were redness of the skin in $168(56.8 \%)$ cases and itching in $36(12.2 \%)$. The five most common diagnoses made as a result of the consultation were unspecified dermatitis in 47 (15.9\%) cases, scabies in 34 (11.5\%), insect bite in $17(5.7 \%)$, atopic dermatitis in 13 (4.4\%), and seborrheic dermatitis in $13(4.4 \%)$. When the diagnoses were examined according to the age groups, unspecified dermatitis was usually seen in the $0-2$, 6-11, and 12-18 years age groups and insect bite was more common in the 3-5 years age group. Conclusion: The establishment of effectively functioning consultation mechanisms not only facilitates a correct diagnosis for the patient and appropriate treatment, but also can shorten the length of hospital stay for patients and can reduce economic costs.
\end{abstract}

Keywords: Pediatrics, Dermatology, Consultation, Diagnoses

Öz

Amaç: Bu çalıșmanın amacı dermatoloji bölümüne konsülte edilen çocuk hastaların klinik, demografik ve tanısal özelliklerini değerlendirmektir.

Materyal-Metod: Ocak 2021 ile Ağustos 2021 tarihleri arasında pediatri kliniğinden istenen dermatoloji konsültasyonları retrospektif olarak değerlendirilmiştir. Hastaların demografik verileri, konsültasyon istenme sebepleri, konsültasyon sonucu verilen tanılar kayıt edilmiștir.

Bulgular: 150'si (50.7\%) kadın ve 146'sı (49.3\%) erkek olmak üzere 296 hasta değerlendirilmiştir. Hastaların ortanca yaşı 5.5 (1.5-10.5) yıl idi Ayaktan hasta polikliniği en çok konsültasyon istenen çocuk kliniği bölümü olarak görülmüştür. En sık konsültasyon istenme sebebi 168 (\%56.8) hastada kızarıklık ve 36 (\%12.2) hastada kaşıntı olarak bulunmuştur. Konsültasyon sonrası en sık verilen 5 tanı 47 (\%15.9) hastada tanımlanmamış dermatit, 34 (\%1 1.5) hastada skabiyez, 17 (\%5.7) hastada haşere ısıı̆ğı, $13(\% 4.4)$ hastada atopik dermatit ve $13(\% 4.4)$ hastada seboreik dermatit olarak bulunmuştur. Yaş grupları arasındaki tanılara bakıldığında tanımlanmamıs dermatit 0-2, 6-11 ve 1218 yaş grubunda daha sık görülürken haşere ısırığı 3-5 yaş grubunda daha sık olduğu görülmüştür. Sonuç: Etkin işleyen konsültasyon mekanizmalarının kurulması, hastaya doğru tanı konulması ve uygun tedaviyi sağlamanın yanı sıra, hastaların hastanede kalış sürelerini kısaltabilir ve ekonomik maliyetleri azaltabilir.

Anahtar kelimeler: Pediatri, Dermatoloji, Konsültasyon, Tan

\section{Introduction}

Although the majority of the dermatology department inpatients. Just as for every branch, there is a demand patient group are outpatients, the importance for opinions and help on the subject of problems of consultations from other clinics are becoming related to the branch of dermatology. Although more important. Consultations are important for the dermatological problems may be associated with a diagnosis, treatment and follow up of patients (1). primary dermatological disease, they may also be seen There may be dermatological problems in patients in the form of skin findings of accompanying systemic seen in the pediatric emergency department, the diseases. pediatric outpatient clinic and the pediatric wards of 
That primary dermatoses can be seen in the pediatric age group and that skin findings occur in many inflammatory, infective, and systemic diseases increase the importance of dermatology consultations. The assistance of dermatology consultations provides the advantages of correct diagnosis and effective treatment and a shorter length of stay in hospital for the patient. Dermatology consultations of patients encountered on the pediatric clinics are important in the training of healthcare personnel, especially in tertiary level training hospitals (2).

The majority of pediatricians who are first consulted about diseases that involve the skin and can be seen in the pediatric age group are specialists. It has been determined that a third (9\%-32\%) of pediatric consultations are generally with the dermatology department $(3,4)$. Pediatric dermatology is special and important for both branches. The aim of this study was to evaluate the clinical, demographic, and diagnostic characteristics of pediatric patients consulted to the dermatology department.

\section{Materials and Methods}

The study was conducted in accordance with the principles of the Helsinki Declaration. Approval for the study was granted by the Local Ethics Committee (Konya City Hospital, TUEK Commission, decision no:799, dated:2021).

Patients who were consulted to the dermatology department from Konya City Hospital pediatric emergency department, pediatric outpatient clinics and pediatric inpatient service between January 2021 and August 2021 were scanned retrospectively. All the patients were evaluated by a pediatrician and a dermatologist. The demographic data of the patients, the pediatric department requesting consultation, their complaints at admission, the reasons for asking for consultation, and the diagnoses they received as a result of the consultation were recorded.

\section{Statistical Analysis}

Statistical Package for Social Sciences (SPSS) Windows software (ver. 22; IBM SPSS, Chicago, USA) was used for all statistical analyses. Descriptive statistical methods were used in the analysis of the data. Normality tests including Kolmogorov-Smirnov and Shapiro-Wilk tests, was used to determine the distribution of data. Normally distributed data were expressed as mean \pm standard deviation, and not normally distributed data were expressed as median (25th-75th percentile). Categorical variables were specified as number (n) and percentage (\%).

\section{Results}

A total of 296 patients, 150 (50.7\%) females and 146 (49.3\%) males, with a median age of 5.5 (1.5-10.5) years and an age range of 1 day -18 years were evaluated. The outpatient clinic was reported to have made the most requests for consultation, followed by the emergency department and the inpatient wards (Table 1).

Table 1. Distribution of patients according to demographic and clinical characteristics

$\begin{array}{lll} & & \mathrm{n}(\%) \\ \text { Sex } & \text { Female } & 150(50.7) \\ & \text { Male } & 146(49.3) \\ \text { Age-years } & 0-2 & 89(30.1) \\ & 3-5 & 56(18.9) \\ & 6-11 & 87(29.4) \\ \text { Pediatric division } & \text { Emergency } & 30(21.6) \\ & \text { Outpatient } & 239(80.7) \\ \text { Clinic } & & 27(9.1) \\ & \text { Inpatient } & \end{array}$

Table 2. Distribution of patients according to their complaints

$\begin{array}{llll}\text { Complaints } & \mathrm{n}(\%) & \text { Complaints } & \mathrm{n}(\%) \\ \text { Rash } & \begin{array}{l}168 \\ (56.8)\end{array} & \text { Acne } & 5(1.7) \\ \text { Pruritus } & 36 & & \\ & (12.2) & \text { Darkness of skin } & 4(1.4) \\ \text { Hair loss } & 16(5.4) & \text { Mass } & 4(1.4) \\ \text { Swelling } & 11(3.7) & \text { Light spot } & 3(1.0) \\ \text { Diaper dermatitis } & 8(2.7) & \text { Ulcers } & 2(0.7) \\ \text { Red spot } & 8(2.7) & \text { Bruise } & 2(0.7) \\ \text { Brown spot } & 7(2.4) & \text { White spot on nail } & 2(0.7) \\ \text { Oral ulcers } & 7(2.4) & \text { Whitening of skin } & 1(0.3) \\ \text { White spots } & 6(2.0) & \text { Redness on tongue } & 1(0.3) \\ \text { Dryness } & 5(1.7) & & \end{array}$

The most frequent complaints on presentation were redness of the skin in $168(56.8 \%)$ cases and itching in $36(12.2 \%)$ (Table 2). The five most common diagnoses made as a result of the consultation were unspecified dermatitis in $47(15.9 \%)$ cases, scabies in $34(11.5 \%)$, insect bite in 17 (5.7\%), atopic dermatitis in 13 (4.4\%), and seborrheic dermatitis in $13(4.4 \%)$ (Table 3$)$. The patients were grouped in age ranges of infancy: $0-2$ years, pre-school: 3-5 years, school-age: 6-11 years, and adolescents: 12-18 years. When the diagnoses were examined according to the age groups, unspecified dermatitis was usually more in the 0-2, 6-11, and 12-18 years age groups and insect bite was more common in the 3-5 years age group (Table 4). 
Table 3. Distribution of most frequently seen 22 dermatological disorders,

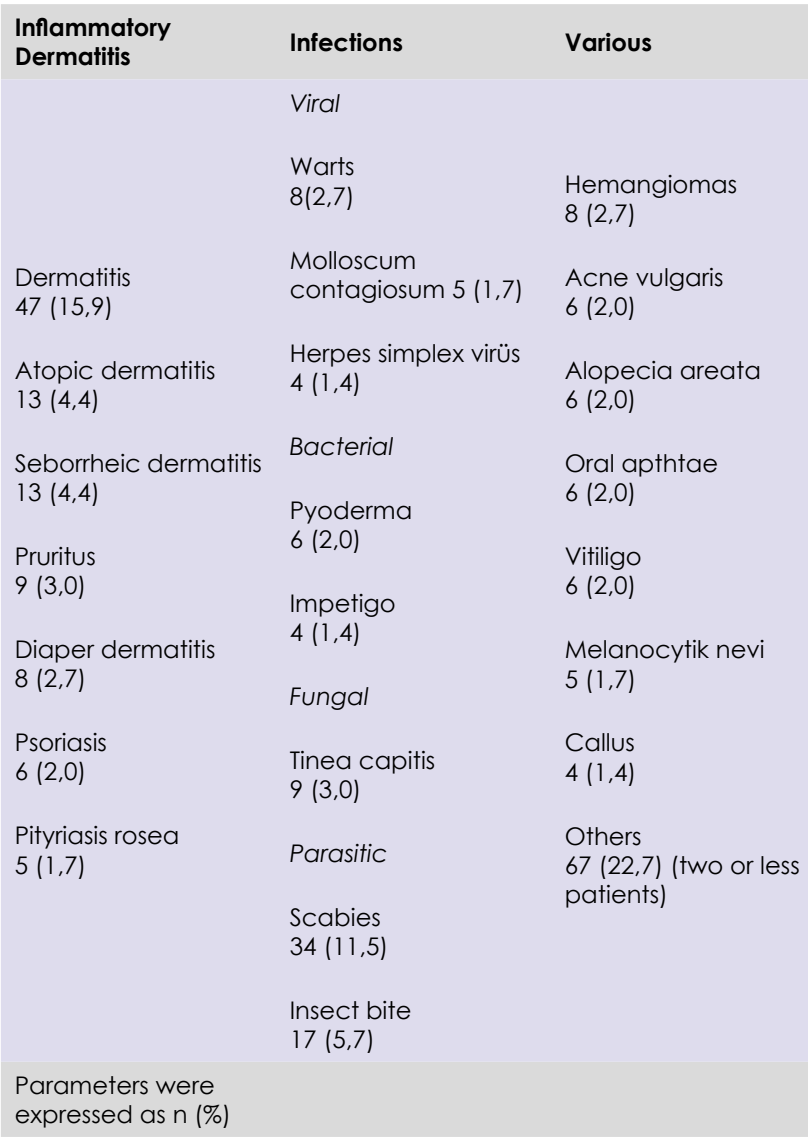

\section{Discussion}

In this single-centre, retrospective study without a control group, 296 patients referred to the dermatology outpatient clinic by various pediatric clinics between
January 2021 and August 2021. The majority of the patients were outpatients. The most common reason for consultation was redness in the skin and as a result of the consultations, most of diagnoses were unspecified dermatitis and scabies.

Just as there may be pathologies related to the skin on presentation at hospital, they may also develop during the follow-up of hospitalization. In addition to the findings of primary dermatological diseases, findings may also present in the form of skin involvement of accompanying diseases (3). Problems related to exposed areas of skin are noticed early but if lesions in areas covered by clothes are not reported by the patient and a thorough physical examination is not made, they can be easily overlooked. Therefore, a detailed physical examination is of great importance in the determination of dermatological problems, especially in pediatric patients (1).

The aim of dermatology consultations is to identify skin pathologies and reveal systemic problems that may be related. In a study by Adisen et al. (5) the majority of dermatology consultations were reported to from the internal diseases department, and both pediatric and adult emergency departments. Consultations requested from pediatric clinics were reported to constitute $21.2 \%$ of all dermatology consultations. Similar to other studies, the majority of the dermatology consultations for the pediatric patient group in this study were found to be requested from pediatric outpatient clinics $(3,67)$.

In this study, there was no difference between the genders. The patients for whom consultation was requested were usually infants or school-age children. Previous studies reported that more consultations were requested in infancy $(3,6)$.

Penate et al. (4) stated that the most common

Table 4. Distribution of most frequently seen 10 dermatological disorders according to age groups

\begin{tabular}{|c|c|c|c|c|c|c|c|}
\hline \multicolumn{2}{|l|}{$\begin{array}{l}0-2 \text { years } \\
n=89\end{array}$} & \multicolumn{2}{|l|}{$\begin{array}{l}3-5 \text { years } \\
n=56\end{array}$} & \multicolumn{2}{|l|}{$\begin{array}{l}6-11 \text { years } \\
n=87\end{array}$} & \multicolumn{2}{|l|}{$\begin{array}{l}12-18 \text { years } \\
n=64\end{array}$} \\
\hline Dermatitis & $20(22.5)$ & Insect bite & $8(14.3)$ & Dermatitis & $12(13.8)$ & Dermatitis & $10(15.6)$ \\
\hline Scabies & $11(12.4)$ & Dermatitis & $5(8.9)$ & Scabies & $12(13.8)$ & Scabies & $8(12.5)$ \\
\hline Atopic dermatitis & $7(7.9)$ & Tinea capitis & $5(8.9)$ & Warts & $5(5.7)$ & Acne vulgaris & $4(6.3)$ \\
\hline Seborrheic dermatit & litis $6(6.7)$ & Atopic dermatitis & $4(7.1)$ & Alopecia areato & $4(4.6)$ & Oral aphtae & $3(4.7)$ \\
\hline Insect bite & $6(6.7)$ & Hemangiomas & $3(5.4)$ & Pityriasis rosea & $4(4.6)$ & Alopecia areata & $2(3.1)$ \\
\hline Diaper dermatitis & $5(5.6)$ & M. contagiosum & $3(5.4)$ & Tinea capitis & $4(4.6)$ & Callus & $2(3.1)$ \\
\hline Hemangiomas & $5(5.6)$ & Pruritus & $3(5.4)$ & Insect bite & $3(3.4)$ & Epidermal cyst & $2(3.1)$ \\
\hline Pruritus & $3(3.4)$ & Seborrheic derma & titis 3 (5.4) & Xerosis cutis & $3(3.4)$ & Contact dermatitis & is $2(3.1)$ \\
\hline Impetigo & $2(2.2)$ & Scabies & $3(5.4)$ & Pruritus & $3(3.4)$ & Psoriasis vulgaris & $2(3.1)$ \\
\hline Pyoderma & $2(2.2)$ & Oral aphtae & $2(3.6)$ & Tinea corporis & $3(3.4)$ & Seborrheic dermat & atitis2 (3.1) \\
\hline Others & $22(24.8)$ & Others & 17 (30.2) & Others & 34 (39.3) & Others & 27 (42.3) \\
\hline
\end{tabular}


diagnoses as a result of pediatric dermatology consultation were inflammatory dermatitis such as atopic dermatitis and seborrheic dermatitis, followed by infections, primarily viral infections. Similarly in this study, the leading diagnosis was inflammatory dermatitis followed by infections, primarily scabies. Inflammatory dermatitis was determined in 81 (27.4\%) of the 296 patients. Inflammatory dermatitis is a finding which can usually be seen in a young age group because of skin sensitivity, and is important as it can be accompanying other comorbid infections.

In a study conducted by Daye et al. (9) it was reported that the majority of pediatric dermatology consultations resulted in a diagnosis of eczema and dermatitis, similar to this study. In patients diagnosed with eczema and dermatitis, this is important as it may be an initial finding of atopic dermatitis, allergic contact dermatitis and other dermatological diseases which can subsequently develop. It is therefore important that this group of patients are followed up as outpatients in the dermatology outpatient clinic.

Unlike other studies, scabies, which has been frequently met in our region in recent years, was the second most common reason for consultation. A diagnosis of scabies was made in 34 (11.5\%) patients in this study. Different studies have shown different results related to scabies encountered in pediatric dermatology consultations. Srinivas et al reported a diagnosis of scabies in 22 (4.5\%) of 486 patients while Afsar et al diagnosed scabies in $1(0.2 \%)$ of 539 patients $(3,7)$.

In two separate studies by McMahon et al and Afsar et al, the pediatric department making the most requests for consultation was the pediatric inpatient wards followed by the pediatric hematology department (6, 7). In this study, the most requests for consultation were from the pediatric outpatient clinics.

In a study by Cruz-Manzano et al. (8) drug reaction was at the rate of $11.5 \%$ in 1427 pediatric consultations, and in this study drug reaction was determined in 1 patient. It was reported that drug reactions occur more in pediatric oncology group patients (8).

When the results of ths study were examined overall, the third most frequent diagnosis after inflammatory dermatitis and infections was found to be hemangioma from vascular anomalies. McMahon et al. (6) reported that vascular anomalies were the second most common reason for hospitalisation. Similar to the study by Afsar et al. (7), the low rate of vascular anomalies seen in consultations in the current study could be due to this group of patients usually being followed up in the dermatology outpatients clinic.

Diagnoses seen at lower rates as a result of consultations were acne vulgaris, alopecia areata, recurrent oral aphthae, and vitiligo. As expected, acne vulgaris was determined most in the adolescent period of 12 18 years, at the rate of $2 \%$, which was similar to the findings of Daye et al (9).

Limitations of this study could be stated as that it was retrospective and conducted in a single centre. The fact that the study was conducted in a tertiary level hospital also makes it difficult to generalize the results. Another limitation was that there was no information about the dermatological treatments applied to the patients and the outcomes.

\section{Conclusion}

Dermatological diseases often occur in childhood. The establishment of effectvely functioning consultation mechanisms not only facilitates a correct diagnosis for the patient and appropriate treatment, but also can shorten the length of hospitalization for pediatric patients and can cost-effective. In this process, we think that the cooperation of the relevant branches and training between the branches will be beneficial. Nevertheless, there is a need for further, prospective, controlled studies of larger number of patients to be able to achieve them and similar benefits.

Conflict of interest: Authors declare no conflict of interest

\section{Funding information: None}

\section{References}

1.Penate Y, Guillermo N, Melwani P, et al. Dermatologists in hospital wards: an 8-year study of dermatology consultations. Dermatology 2009;219(3):225-231.

2.Moon AT, Castelo-Soccio L, Yan AC. Emergency department utilization of pediatric dermatology consultations. J Am Acad Dermatol 2016;74:1173-1177.

3.Srinivas SM, Hiremagalore R, Venkataramaiah LD, et al. Pediatric dermatology inpatient consultations: a retrospective study. Indian J Pediatr 2015;82(6):541-544.

4.Peñate $Y$, Borrego L, Hernández $N$, et al. Pediatric dermatology consultations: a retrospective analysis of inpatient consultations referred to the dermatology service. Pediatr Dermatol 2012;29(1):115118.

5.Adisen E, Ünal S, Gürer MA. Dermatology Consultations. TurkdermArchieves of The Turkish Dermatology and Venerology 2006;40(4):126129.

6.McMahon P, Goddard D, Frieden IJ. Pediatric dermatology inpatient consultations: a retrospective study of 427 cases. J Am Acad Dermatol 2013;68(6):926-931.

7.Afsar FS. Analysis of pediatric dermatology inpatient consultations in a pediatric teaching hospital. Arch Argent Pediatr 2017;1 15(6):377384.

8.Cruz-Manzano M, Brau-Javier CN, Valentin-Nogueras S, FigueroaGuzmán LD. Pediatric Inpatient and Emergency Dermatology Consultations: A 5-Year Retrospective Analysis P R Health Sci J 2018;37:105-109.

9.Daye M, Temiz SA, Durduran Y, Balevi S, Dursun R, Ataseven A, Ozer I. Analysis of Consultation Cases Referred from Pediatrics Department to Dermatology Outpatient Clinic: Retrospective Study. Clin Exp Health Sci 2019; 9: 300-303. 